\title{
The content of soccer club stereotypes - Perceptions of warmth and competence of German Bundesliga and English Premier League clubs
}

Kauff, M. ${ }^{\mathrm{a}^{*}}$, Hellmann, J. H. ${ }^{\mathrm{b}}$, Nigbur, D. ${ }^{\mathrm{c}}$, \& Asbrock, F. ${ }^{\mathrm{d}}$

This is a preprint of the article version submitted for publication.

${ }^{a}$ Department of Psychology, Medical School Hamburg, Hamburg, Germany; ${ }^{b}$ Institute for Psychology, University of Münster, Münster, Germany; ${ }^{c}$ School of Psychology and Life Sciences, Canterbury Christ Church University, Kent, United Kingdom; ${ }^{d}$ Behavioral and Social Sciences, Technical University of Chemnitz, Chemnitz, Germany

*Corresponding author: Medical School Hamburg, Am Kaiserkai 1, 20457 Hamburg, Germany, mathias.kauff@,medicalschool-hamburg.de 


\begin{abstract}
One of the most prominent social-psychological models describing the content of stereotypes about social groups is the Stereotype Content Model. The model assumes that social groups can be clustered along the dimensions of warmth (How well-intentioned is a group?) and competence (How capable is a group to implement its intentions?). We used this model to describe consensually shared stereotypes about soccer clubs from the German Bundesliga and the English Premier League. Using online questionnaires, we asked 681 and 800 participants to rate warmth, competence of as well as general attitudes and certain emotions associated with clubs from the Bundesliga (Study 1) and the Premier League (Study 2). Results indicated that clubs in both leagues can be grouped into three clusters along the dimensions of warmth and competence. Our approach extends previous work that mainly focusses on unidimensional evaluations of clubs.
\end{abstract}




\section{Theoretical background}

Identifying with a professional sports club can be an inherent part of individuals' social identity and positively reflect on peoples' public and self-images ${ }^{1}$. Given that soccer (or Association Football) is the most popular team sport worldwide, identification with soccer teams provides a way to increase one's self-esteem and purpose for many people around the world ${ }^{2}$. Often, positive evaluations associated with one club are related to demarcations against, devaluation of, and deep-rooted rivalry with other clubs ${ }^{3}$. This can explain why Everton fans full-throatedly celebrated Liverpool's disappointing second place finish in the Premier League 2019/2020 season ${ }^{4}$ or why in a German television quiz show a Borussia Mönchengladbach fan refused to give the correct answer to a question because he was unwilling to vocalize the name of the rival club 1 . FC Köln ${ }^{5}$. It has been argued that heartfelt rivalries among sports fans serve various functions, especially when a rival team loses. These functions include schadenfreude and a sense of satisfaction ${ }^{6}$. The evaluation of soccer teams may be an antecedent of how their fans are seen and ultimately treated by fans of other soccer clubs.

In addition to rather idiosyncratic evaluations of rival clubs there are often broadly shared images and stereotypes of certain clubs. For example, in the English Premier League, some clubs are more disliked or hated than others ${ }^{7}$. In the German Bundesliga, RB Leipzig, a club founded by the company Red Bull, is disliked by many because it is seen as a successful but over-capitalistic enterprise that lacks tradition ${ }^{8}$. In the present paper, we sought to study consensually shared images of soccer clubs in the German Bundesliga and the English Premier League. In contrast to earlier research, we did not build on uni-dimensional evaluations of clubs, but on a well-established two-dimensional model of stereotype content ${ }^{9}$.

\section{The stereotype content of soccer teams}

Most surveys addressing public images of soccer clubs refer to uni-dimensional evaluations of the respective clubs. In Germany, for example, an annual survey by 
Woisetschläger and colleagues provides a brand ranking of German clubs that is based on ratings of attractiveness and popularity ${ }^{10}$. Moreover, there are global ratings of clubs' value. Among the ten most valuable clubs globally, there are, for example, six clubs from the English Premier League ${ }^{11}$, which might also reflect clubs' standing among soccer fans around the globe.

In contrast to these approaches, we argue that soccer clubs can also elicit ambivalent images. German championship record-holder Bayern Munich, for example, is widely respected for its financial and sporting success but despised by many for its great number of transfers and aggressive communication ${ }^{12}$. Hence, we build on a well-established socialpsychological model of (ambivalent) group stereotypes and measure evaluations of clubs on two dimensions, warmth and competence.

The Stereotype Content Model (SCM) ${ }^{13}$ builds on the notion that warmth and competence are the fundamental dimensions in perception of individuals but also social groups ${ }^{14}$.Warmth provides an answer to the other's perceived intentions ("good or bad"?), and competence provides information on the other's perceived capabilities to implement these intentions. Accordingly, Fiske et al. as well as Cuddy et al. argued that social groups can be clustered along these dimensions. ${ }^{15}$ In their studies, they asked participants for societal perceptions of a variety of social groups. While some groups were perceived as warm and competent (first and foremost majority ingroups in the surveyed countries such as White Christians in the USA) or cold and incompetent (e.g., welfare recipients or homeless people) other groups were situated in ambivalent clusters. Elderly and disabled persons in the USA were regarded as warm but incompetent while Asians, Jews, feminists, and the rich were perceived as cold but competent.

The SCM assumes that the warmth and competence clusters are associated with specific emotional and behavioural reactions. While groups in the low-warmth-lowcompetence cluster have been shown to elicit contempt, groups in the high-warmth-high- 
competence cluster elicit admiration, groups in the low-warmth-high-competence cluster elicit envy, and groups in the high-warmth-low-competence cluster elicit pity. ${ }^{16}$ Moreover, with regard to behavioural reactions, warm groups elicit active facilitation (e.g., helping) and cold groups active harm (e.g., fighting) while competent groups elicit passive facilitation (e.g., cooperation) and incompetent groups elicit passive harm (e.g., exclusion). ${ }^{17}$

This warmth-competence framework has been shown to be a reliable and valid indicator of group perception ${ }^{18}$, utilized in different cultural contexts ${ }^{19}$, and for different types of groups. Drawing on past research on this framework outside the domain of societal groups $^{20}$, it is reasonable to assume its applicability to soccer clubs. In the present paper, we, hence, aimed at testing the SCM in the context of soccer clubs. More precisely, we sought to study whether soccer clubs can be located in distinct clusters along the dimensions of warmth and competence (Research Question 1). Moreover, we tested whether these clusters are associated with certain emotions (Research Question 2). Furthermore, we considered broader measures of the evaluation of soccer clubs and how these were related to warmth and competence: We examined whether warmth and competence are related to participants' suggestions about funding allocations as well as their overall assessment of each club (Research Question 3).

\section{Study 1 - Perceptions of the German Bundesliga clubs}

\section{Method}

All participants provided informed consent online. The present research adheres to the principles stated in the Declaration of Helsinki. In line with local ethics regulation and given that we did not gather participants' personal information, that the research did not include deception, or unsettling, distressing, or dangerous material we did not obtain formal ethical approval. 
We report how we determined our sample size, all data exclusions (if any), all manipulations, and all measures for both studies ${ }^{21}$.

Data of both studies are available at https://osf.io/gcsvu/. Study 1 was preregistered (https://osf.io/urt5c) $)^{\mathrm{I}}$

\section{Participants}

Data of Study 1 were collected online in August and September, 2020 - a few weeks before the start of the 2020/2021 season. Participants were approached via Twitter and postings in a popular German soccer internet forum as well as via the data collection platform Prolific. A total of 681 participants filled in the online questionnaire. No data were excluded. Sample size was not determined beforehand. However, data collection for the study had a fixed end date. We tried to collect data from as many participants as possible.

Participants' age ranged between 17 and 81 years with a mean of $35.05(S D=12.41)$. Eighty-eight percent of the participants were male, 11.6 percent female, and 0.4 percent indicated "diverse" as their gender. The vast majority (94 percent) of the participants indicated that they had a favourite club (see Supplemental Material for an overview of frequencies). Of these, 58 percent specified that they seldom watch games at the stadium while 35 percent indicated that they regularly watch home and away games of their favourite sides at the stadium.

\footnotetext{
${ }^{\text {I }}$ Please note that this preregistration was part of a student project and contains some rather imprecise information. Nevertheless, for the sake of transparency and as evidence of preregistration of the general idea of our study we included the link to the preregistration.
} 


\section{Measures}

Besides sociodemographic variables (i.e., age, gender, favourite club, commitment to favourite club), participants indicated their perceptions of consensual stereotypes of the clubs on competence, warmth, and traditionality ${ }^{\mathrm{II}}$. Moreover, we measured perceived consensual emotions, individuals' preferences regarding money distribution to the clubs as well as participants' overall assessment of the clubs. All items were measured on a five-point rating scale from 1 (not at all/very negative) to 5 (very much/very positive). We measured perceived consensual attitudes towards the clubs rather than individual attitudes to decrease social desirability and influences of own club affiliation as well as to get a better idea of club perceptions shared among the greater soccer supporter community. ${ }^{22}$ The majority of items was adapted from Asbrock, Cuddy et al., and Fiske et al. ${ }^{23}$

To avoid fatigue, participants rated a randomly assigned selection of six of the 18 Bundesliga clubs. The total number of ratings for each club ranged from 144 to 377 with a mean of $255.78(S D=56.81)$.

Warmth was measured with three items (e.g., "As viewed by society, how much warmth does the club radiate?", see Supplemental Material for a list of all items). The items formed a reliable scale (Cronbach's $\alpha$ s ranged between .74 and .87 ) and were, hence, aggregated to form a composite score. Competence was measured with three items (e.g., "As viewed by society, how competent are the actors of this club?", see Supplemental Material for

\footnotetext{
II Traditionality was included based on the idea that traditional versus modern beliefs are another fundamental dimension of group stereotypes ${ }^{24}$. However, we were unable to reliably measure this construct in the context of soccer clubs. Moreover, the single items measuring traditionality did not systematically improve the predictive value of our models. Traditionality, hence, is not further considered in this manuscript. For a cluster solution including traditionality, see Supplemental Material.
} 
a list of all items). With three exceptions (i.e., Bayern: Cronbach's $\alpha=.32$; Freiburg:

Cronbach's $\alpha=.40$; Hertha: Cronbach's $\alpha=.39$ ), the items built a reliable scale (Cronbach's $\alpha$ ranged between .57 and .71). In line with previous research and for comparability with prior

studies $^{25}$, the three competence items were also aggregated to form a composite score.

Emotions (i.e., admiration, envy, contempt, and pity) were each measured with a single item (“As viewed by society, how much is this club admired/envied/felt contempt for/pitied?”).

Preferred money distribution was also measured with a single item ("Should the club receive more money [e.g., broadcasting revenues and governmental support] than other clubs?"), as was overall assessment ("What do you think, how is the overall assessment of this club?"). High values represent a preference for a higher pay-out for and more favourable assessment of the respective club.

Participants' individual responses to all constructs were aggregated to form a mean score for each variable of interest for each club. All analyses described below were carried out with the aggregated data (i.e., data including, for example, the average warmth and competence ratings for each club).

\section{Results and discussion}

In this section, we will first portray results of a cluster analysis outlining how the 18 German Bundesliga clubs can be grouped along the dimensions of warmth and competence (Research Question 1). We will, then, depict the relationship between clusters and specific emotions (Research Question 2). Finally, we will present the results of regression analyses addressing the relationship between warmth and competence on the one hand and preferred 
money distribution and overall assessment of clubs on the other hand (Research Question 3). ${ }^{\text {III }}$

Cluster analysis of the 18 Bundesliga clubs along warmth and competence dimensions

Table 1 gives an overview of descriptive statistics.

Table 1: Range, means and standard deviations for variables in Study 1.

\begin{tabular}{lrrrr}
\hline & \multicolumn{1}{l}{ Min } & Max & Mean & \multicolumn{1}{l}{$S D$} \\
\hline Warmth & 1.96 & 4.23 & 3.02 & 0.61 \\
Competence & 2.47 & 4.51 & 3.19 & 0.60 \\
Preferred money distribution & 1.96 & 3.60 & 2.89 & 0.49 \\
Overall assessment & 1.94 & 4.36 & 3.24 & 0.69 \\
Admiration & 1.97 & 3.75 & 2.78 & 0.63 \\
Envy & & & & \\
Contempt & 2.10 & 4.26 & 2.63 & 0.57 \\
Pity & 1.44 & 4.39 & 2.76 & 0.79 \\
\hline
\end{tabular}

Note. Response scales ranged from 1 to 5, with higher values indicating stronger agreement.

To get an idea of how the clubs can be grouped along the dimensions warmth and competence, we ran a k-means cluster analysis with JASP $0.11 .1{ }^{26}$ Results indicated a threecluster solution $\left(\mathrm{R}^{2}=.68, \mathrm{BIC}=28.09, \mathrm{AIC}=22.75\right)$. Cluster 1 consists of Bayern Munich, Borussia Dortmund, and RB Leipzig. Cluster 2 comprises Borussia Mönchengladbach,

\footnotetext{
${ }^{\mathrm{III}}$ As a robustness check all analyses were additionally carried out with reduced samples excluding fans of specific clubs. Overall, cluster solutions as well as ratings of the respective clubs as well as their rival clubs were similar. The same holds true for the results of Study 2 .
} 
Eintracht Frankfurt, SC Freiburg, Union Berlin, 1.FC Köln, Mainz 05, Werder Bremen, Arminia Bielefeld, and FC Augsburg. Bayer Leverkusen, TSG Hoffenheim, VfL Wolfsburg, VfB Stuttgart, Hertha BSC, and Schalke 04 are grouped in Cluster 3 (see Figure 1). While clubs in Cluster 1 score higher on competence than clubs in Clusters 2 and $3(p s<.001)$ clubs in Cluster 2 score higher in warmth than clubs in Clusters 1 and $3(p s<.002)$.

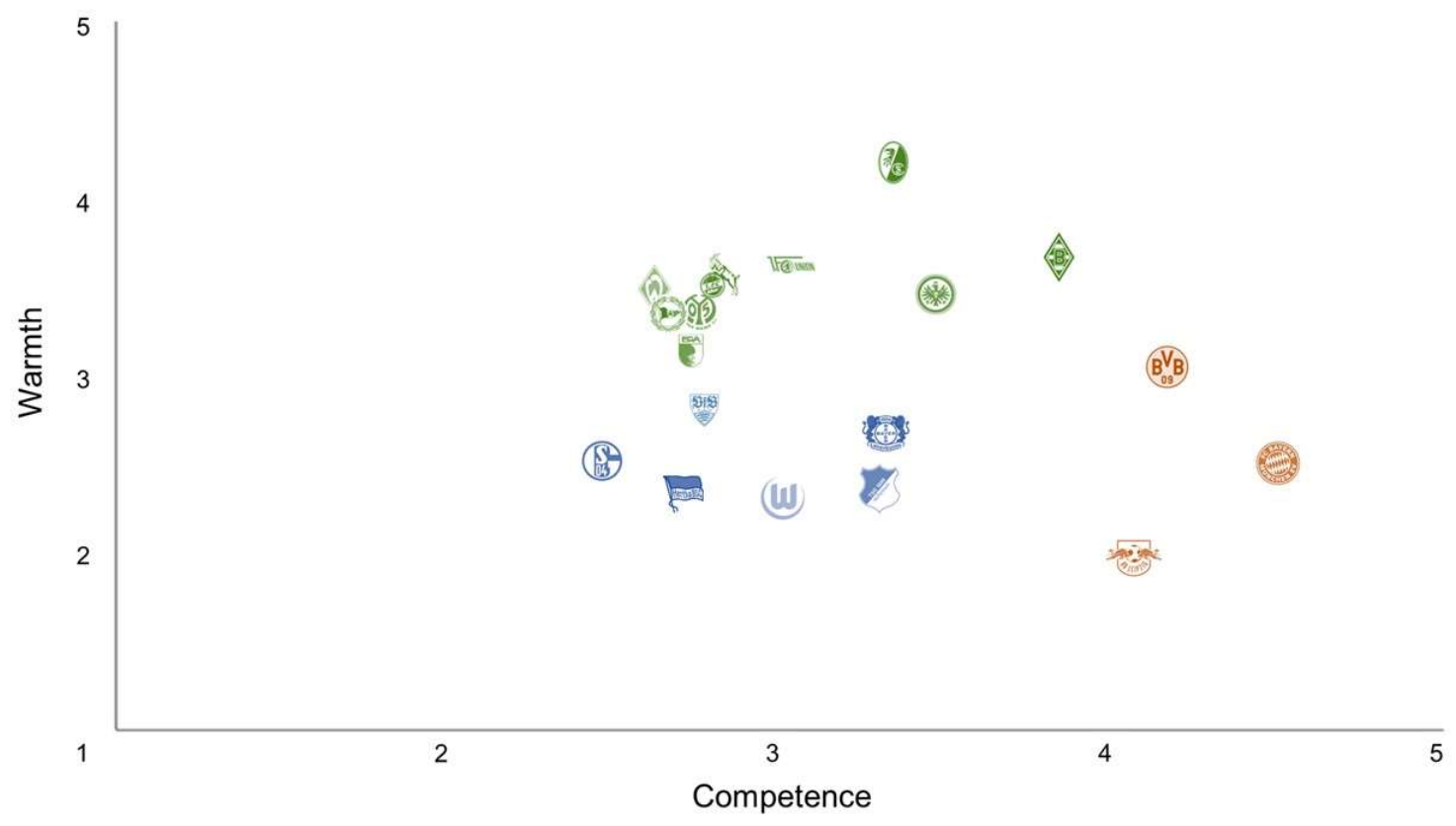

Figure 1: Graphical illustration of the results of a k-means cluster analysis (Study 1).

Relationship between clusters and specific emotions

According to the SCM, warmth-competence clusters are associated with specific emotions. ${ }^{27}$ Hence, we ran analyses of variance to test whether the clusters we found are associated with one or more of the emotions typically associated with warmth-competenceclusters.

Clubs in Cluster 1 elicited more envy $(p \mathrm{~s}<.001)$ and less pity than the clubs in Clusters 2 and $3(p s<.009)$. Clubs in Cluster 2 elicited less contempt than the clubs in 
Clusters 1 and $3(p \mathrm{~s}<.002)$, and clubs in Cluster 3 elicited less admiration than clubs in

Clusters 2 and $3(p s<.002)$.

Warmth and competence as predictors of preferred money distribution and overall assessment of clubs

To test the extent to which warmth and competence predicted participants' preferences regarding money distribution to clubs as well as the overall assessment of Bundesliga clubs, we ran linear regressions (see Table 2). Warmth $(b=0.697, S E=0.047, p<.001)$ and competence $(b=-0.283, S E=0.047, p<.001)$ significantly predicted preferred money distribution. Surprisingly, the relationship between competence and preferences for a higher pay-out for clubs was negative. Warmth $(b=1.089, S E=0.090, p<.001)$ and competence $(b$ $=0.290, S E=0.092, p=.006)$ also significantly predicted the overall assessment of clubs.

Table 2: Standardized regression coefficients for linear regressions of preferred money distribution and overall assessment on warmth and competence in Study 1 (unstandardized coefficients and standard errors can be found in the text).

\begin{tabular}{lcccr}
\hline & $\begin{array}{l}\text { Preferred money } \\
\text { distribution }\end{array}$ & \multicolumn{2}{c}{ Overall assessment } \\
\hline Warmth & $\beta$ & $p$ & $\beta$ & $p$ \\
\hline Competence & 0.865 & $<.001$ & 0.955 & $<.001$ \\
& & & & \\
& -0.345 & $<.001$ & 0.251 & .006 \\
\hline
\end{tabular}

\section{Summary of results}

In line with previous work on stereotype content, the clubs could be meaningfully grouped in three different clusters. Cluster 1 represents the most competent clubs (e.g., Bayern Munich) 
and goes along with high envy and low pity. Cluster 2 represents the warmest clubs (e.g., SC Freiburg) and goes along with low contempt. Cluster 3 represents all other clubs and goes along with low admiration.

The overall assessment of clubs is related to both ratings of consensual perceptions of warmth and competence. Interestingly, preferred distribution of financial resources to clubs was positively related to warmth but negatively related to competence. In other words, participants apparently preferred a distribution of financial resources that contradicts the present approach by the Bundesliga and may produce more equal opportunities for clubs in the long run. At this point, it is important to note that competence ratings were highly correlated with clubs' final position in the league at the end of the previous season $\left(r_{s}=-.85\right.$, $p<.001)$. We note that this correlation is negative because the highest rank is represented by the lowest number.

\section{Study 2 - Perceptions of the English Premier League clubs}

\section{Method}

Participants in Study 2 answered an online questionnaire measuring sociodemographic variables, as well as attitudes and emotions towards the 20 Premier League clubs competing in the season 2020/2021. Study 2 was preregistered (https://osf.io/v3wj7).

\section{Participants}

Data of Study 2 were collected in November 2020 after the end of the ninth and before the start of the tenth match week. Data were collected via the platform Prolific. A total of $N=$ 812 participants filled in the online questionnaire. No data were excluded. Before data collection started, we determined to gather data from 800 individuals based on financial resources that could be distributed to this project. Participants' age ranged between 18 and 79 years with a mean of $35.67(S D=13.57)$. Sixty-one percent of the participants were male, 
38.8 percent female, and 0.1 percent indicated "diverse" as their gender. The vast majority (94 percent) of the participants indicated that they had a favourite club (see Supplemental Material for an overview of frequencies). Of these, 80 percent specified that they seldom watch matches at the stadium while 5 percent indicated that they regularly watch home and away games of their favourite clubs at the stadium.

\section{Measures}

Sociodemographic variables (i.e., age, gender, favourite club, commitment to favourite club), societal perceptions of competence (Cronbach's $\alpha$ s ranged between .65 and .85 ), warmth (Cronbach's $\alpha$ s ranged between .68 and .90), emotions, individuals' preferences regarding money distribution to the clubs as well as the overall assessment of the clubs were measured with the same items used in Study 1.

To avoid fatigue, participants rated 5 of the 20 Premier League clubs. The selection of the clubs was random. The total number of ratings for each club ranged from 186 to 226 with a mean of $200.85(S D=11.63)$.

\section{Results and discussion}

As in Study 1, we first portray results of a cluster analysis with the dimensions warmth and competence (Research Question 1), studied the relationship between clusters and specific emotions (Research Question 2) and then analysed the relationship between warmth and competence on the one hand and preferred money distribution and overall assessment of clubs on the other hand (Research Question 3).

Cluster analysis of the 20 Premier League clubs along warmth and competence dimensions

Table 3 gives an overview of the descriptive statistics. 
Table 3: Range, means and standard deviations for variables under study in Study 2.

\begin{tabular}{lrrrr}
\hline & \multicolumn{1}{l}{ Min } & Max & Mean & \multicolumn{1}{l}{$S D$} \\
\hline Warmth & 2.70 & 3.84 & 3.18 & 0.28 \\
Competence & 2.58 & 4.36 & 3.32 & 0.57 \\
Preferred money distribution & 2.55 & 3.20 & 2.99 & 0.17 \\
Overall assessment & 2.81 & 4.12 & 3.37 & 0.36 \\
Admiration & 2.66 & 4.02 & 3.19 & 0.37 \\
Envy & & & & \\
Contempt & 2.05 & 3.92 & 2.78 & 0.61 \\
Pity & 2.35 & 3.65 & 2.83 & 0.34 \\
\end{tabular}

Note. Response scales ranged from 1 to 5 , with higher values indicating stronger agreement.

Results of a k-means cluster analysis with JASP $0.11 .1^{28}$ indicate a three-cluster solution $\left(\mathrm{R}^{2}=.68, \mathrm{BIC}=30.25, \mathrm{AIC}=24.28\right)$. Cluster 1 consists of Everton, Liverpool, Leicester, Southampton, and Wolverhampton. Cluster 2 comprises Arsenal, Chelsea, Manchester City, Manchester United, and Tottenham. Aston Villa, Brighton, Burnley, Crystal Palace, Fulham, Leeds, Newcastle, Sheffield Utd, West Brom, and West Ham are grouped in Cluster 3 (see Figure 2). While clubs in Cluster 1 score higher on warmth than clubs in Clusters 2 and $3(p \mathrm{~s}<.05)$, clubs in Cluster 2 score lower in warmth than clubs in Clusters 1 and $3(p s<.05)$, and clubs in Cluster 3 score lower in competence than clubs in Clusters 1 and $2(p s<.001)$. 


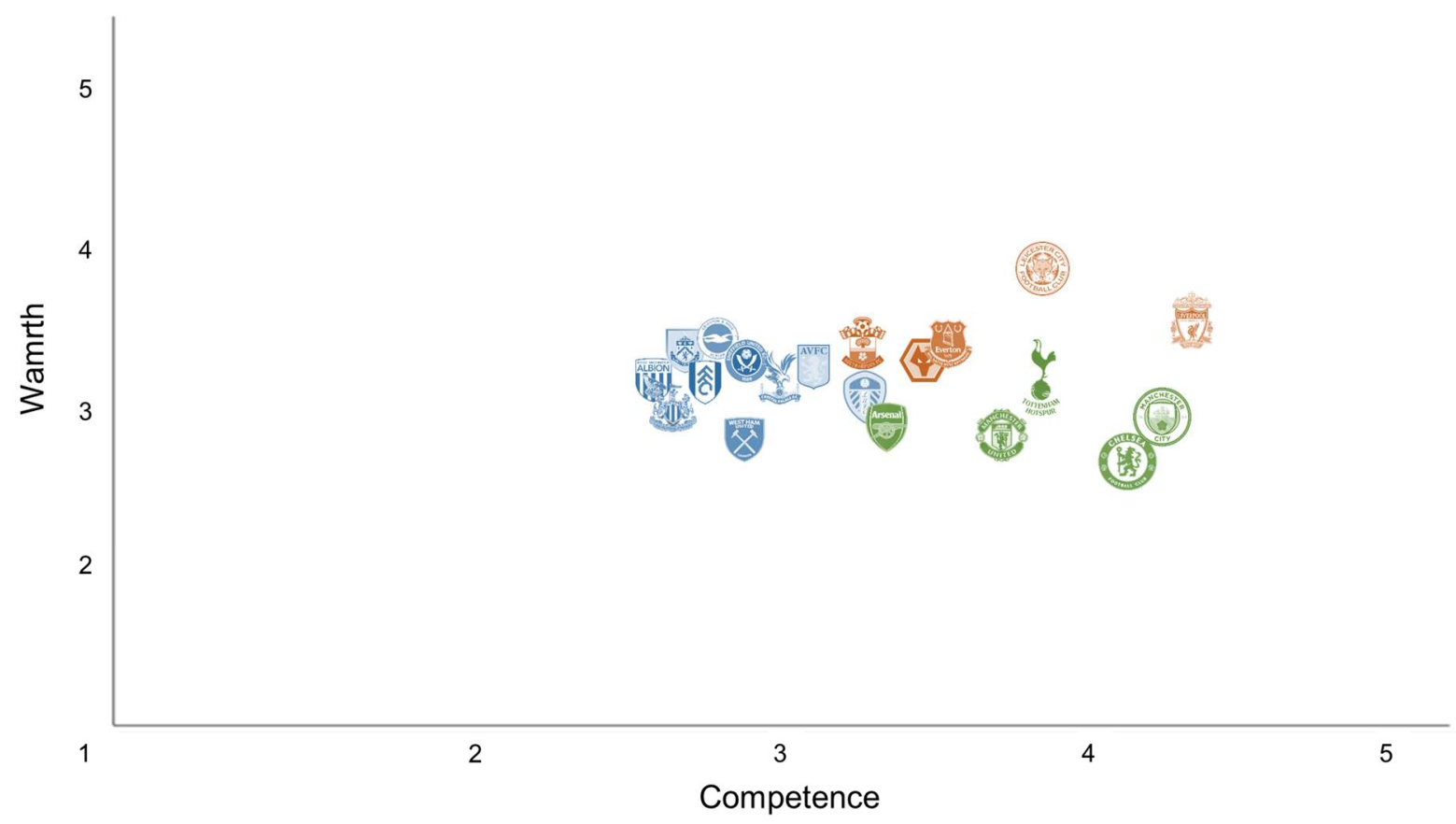

Figure 2: Graphical illustration of the results of a k-means cluster analysis (Study 2).

Relationship between clusters and specific emotions

Analyses of variance with emotions as dependent variable indicated that clubs in Cluster 2 elicit more contempt $(p \mathrm{~s}<.003)$ and envy $(p \mathrm{~s}<.019)$ than the clubs in Clusters 1 and 3. Moreover, clubs in Cluster 3 elicit less admiration and more pity than clubs in Clusters 2 and $3(p s<.002)$.

Warmth and competence as predictors of preferred money distribution and overall assessment of clubs

As in Study 1, we ran linear regressions to test whether warmth and competence predict participants' preferences regarding money distribution to clubs as well as the overall assessment of Premier League clubs (see Table 4). Warmth $(b=0.437, S E=0.069, p<.001)$ and competence $(b=-0.163, S E=0.034, p<.001)$ significantly predicted preferred money distribution. Again, the relationship between competence and preferences for a higher pay-out 
for clubs was negative. Warmth $(b=0.471, S E=0.079, p<.001)$ and competence $(b=0.571$, $S E=0.039, p<.001)$ also significantly predicted the overall assessment of clubs.

Table 4: Standardized regression coefficients for linear regressions of preferred money distribution and overall assessment on warmth and competence in Study 2 (unstandardized coefficients and standard errors can be found in the text).

\begin{tabular}{lcccc}
\hline & $\begin{array}{l}\text { Preferred money } \\
\text { distribution }\end{array}$ & \multicolumn{3}{c}{ Overall assessment } \\
& $\beta$ & $p$ & $\beta$ & $p$ \\
\hline Warmth & 0.702 & $<.001$ & 0.360 & $<.001$ \\
& & & & \\
Competence & -0.540 & $<.001$ & 0.900 & $<.001$ \\
& & & & \\
\hline
\end{tabular}

\section{Summary of results}

Results of Study 2 suggest that the 20 Premier League clubs could also be meaningfully grouped in three clusters. Cluster 1 represents the warmest clubs (e.g., Leicester). Cluster 2 represents the least warm clubs (e.g., Chelsea) and goes along with high contempt and envy. Cluster 3 represents the least competent clubs and goes along with low admiration and high pity.

Regarding the relationship between warmth and preferred distribution of financial resources as well as the overall assessment of clubs, results from Study 2 replicated the pattern from Study 1. Again the preferred distribution of financial resources to clubs was positively related to warmth but negatively related to competence. As in Study 1, competence ratings were related to clubs' final position in the league at the end of the previous season $\left(r_{s}\right.$ $=-.79, p<.001)$ 


\section{General discussion}

In the present research, we applied a social-psychological framework of stereotype content $^{29}$ to soccer clubs in the German Bundesliga as well as the English Premier League. We asked a substantial number of German and English soccer fans about their perceptions of the societal perspective on soccer clubs' warmth, competence, and emotions.

In both studies, clubs could be grouped in three clusters along the dimensions of warmth and competence. Although the number of clusters coincided, their content differed between studies. In both studies one cluster included especially warm clubs (Cluster 2 in Study 1, e.g., Eintracht Frankfurt, Mainz 05, and Cluster 1 in Study 2, e.g., Everton and Liverpool). The remaining clusters, however, differed between the studies. In Study 1 we observed an additional cluster of Bundesliga clubs with especially high competence (e.g., Bayern Munich and Borussia Dortmund) as well as a cluster of clubs (e.g., Bayer Leverkusen and Schalke 04) that was lower in competence than the competent cluster and lower in warmth than the warm cluster. In Study 2, we observed an additional cluster of Premier League clubs (e.g., Arsenal and Chelsea) that was lower in warmth than the other clusters as well as a cluster of clubs (e.g., Aston Villa and Fulham) that was lower in competence than the other clusters.

To sum up, for the Bundesliga we observed a high-warmth cluster, a highcompetence-cluster, as well as a cluster with clubs that are perceived as neither particular warm nor particular competent. For the Premier League we observed a high-warmth cluster, a low-warmth-cluster, and a low-competence cluster.

Noteworthy and in contrast to the predictions of the SCM, none of the clusters in both studies was ambivalent in the sense that one dimension was rated very high and the other dimension was rated very low (see Supplemental Material for an overview of means in competence and warmth for all clusters). In fact, only Cluster 1 in Study 1 tends to show a certain ambivalence - that is, clubs in this cluster were rated as high in competence $(M=4.23$, 
$S D=0.25)$ and relatively low in warmth $(M=2.53, S D=0.58)$. However, warmth ratings are not significantly lower than warmth ratings for Cluster $2(p=.31)$ and not significantly different from the scale midpoint $(p=.30)$.

Although the clusters were related to distinct emotions no systematic pattern of relations between clusters and emotions could be observed across both studies.

Interestingly, in both studies the amount of money that should be distributed to clubs was positively related to clubs' warmth but negatively related to clubs' competence. Given that competence ratings are likely to be at least partially related to clubs' soccer-related success (see high correlation between competence ratings and position in the league in both studies) this contradicts the current system of distribution of broadcasting payments in the Premier League and especially the Bundesliga. While in practice higher payments are made to successful clubs, participants in both studies advocated for a system in which warm as well as less competent (i.e., less successful) clubs receive higher payments. Apparently, participants preferred a compensatory system in which less successful clubs (in both economic and sporting terms) are granted higher funds than more successful clubs. Interestingly, a similar notion can be found in recent debates about the distribution of broadcasting payments among Bundesliga clubs: To break the dominance of a few advantaged clubs (first and foremost Bayern Munich) smaller clubs have urged a review of the current system that strongly favours the top clubs. ${ }^{30}$

Unlike the preferred distribution of money, general evaluations of clubs were positively predicted by both warmth and competence. Generally, overall ratings of clubs were fairly benevolent.

One additional question that should be discussed is the consensus of ratings for the different clubs. Participants were asked to estimate the images of clubs from a broader societal perspective. Nevertheless, a glance at the variances for the variables of interest suggests that for some clubs there seemed to be more dissent than for other clubs. For 
example, variances for warmth ratings of Bayern Munich or competence ratings of Newcastle United are higher than others, indicating that some clubs might be more polarizing in certain aspects than others.

\section{Limitations}

Besides this open question, there are additional limitations of our research. First, it is important to note that the present results are, of course, influenced by the current situation of clubs and, hence, not time-invariant. It is highly likely that recent events contributed to the images that clubs elicit. Liverpool, for example, may have gained warmth in the past five years since Jürgen Klopp became manager. Schalke, on the other hand, is currently struggling financially and fighting for survival in the league and was, consequently, rated as the least competent Bundesliga club. Some years ago, Schalke regularly qualified for the Champions League and had a very different public image.

The data were extensive, but not representative. We, hence, cannot derive any conclusion about whether the clusters we found can be generalized to the whole population of soccer fans in Germany and England. We also asked each participant only to provide ratings for a selection of clubs. Therefore, the numbers of ratings per club were somewhat limited. Additionally, participants only indicated their favorite club, but did not refer to any rival clubs they dislike. In the future, research might consider devaluations of rival clubs and how they go along with negative ratings.

Finally, data were correlational and do not allow for any causal conclusions.

\section{Outlook and conclusion}

Despite these limitations, we believe that our study's contribution to the literature is threefold. Firstly, we applied the social-psychological Stereotype Content Model $^{31}$ to soccer clubs and showed that clubs can be clustered in a warmth-competence matrix. To our knowledge, this is the first application of the model to sports teams. 
Secondly, we presented a rare example of research on evaluations of soccer clubs that goes beyond a unidimensional approach and does not only consider clubs' popularity, prominence, success, or brand value, but the ratings of clubs on two fundamental dimensions of humans' social perception, namely, warmth and competence. We believe that future research could extend our work and use this framework to understand why certain clubs elicit specific emotional (e.g., envy) or behavioural reactions (e.g., rivalry behavior such as attacks of fans). Moreover, the fact that a model that is designed to explain stereotypes in the context of intergroup relations between societal groups is applicable to soccer, once again, nicely illustrates that soccer can be regarded as a social prism of society.

Thirdly, the present research may be a starting point for more thorough investigations of derogatory behavior toward others - merely because of their support of a rival soccer club. Such studies may build on the present research as well as on prior analyses of European football (or soccer) rivalries. ${ }^{32}$

\section{Notes}

1. Cialdini et al., 'Basking in Reflected Glory'; Russell, 'Associating with Football'; and Tajfel, Turner, 'Integrative Theory of Intergroup Conflict'.

2. Porat, 'Football Fandom'.

3. Havard, 'Glory Out of Reflected Failure'.

4. Everton Spare Tickets, 'Arriving home'.

5. Spiegel, ‘Nach Quizshow Gladbach will Fan belohnen'.

6. Havard, 'Glory Out of Reflected Failure'.

7. D'Souza, 'English Premier League'.

8. Dinkelaker, 'Applaus?'.

9. Fiske et al., 'Model of (Often Mixed) Stereotype Content'. 
10. Woisetschläger et al., 'Fußballstudie 2019'.

11. Statista, 'Most valuable football brands'.

12. Oltermann, 'Bayern Munich are the club Germans love to hate'.

13. Fiske et al., 'Model of (Often Mixed) Stereotype Content';

14. Fiske, 'Stereotype Content: Warmth and Competence Endure'.

15. Fiske et al., 'Model of (Often Mixed) Stereotype Content'; Cuddy, Fiske, Glick, 'The BIAS Map'.

16. Cuddy et al., 'Stereotype Content Model across Cultures'; Fiske, 'Stereotype Content: Warmth and Competence Endure'; and Fiske et al., 'Model of (Often Mixed) Stereotype Content'.

17. Cuddy, Fiske, Glick, 'The BIAS Map'.

18. Fiske, 'Stereotype Content: Warmth and Competence Endure'.

19. Cuddy et al., 'Stereotype Content Model across Cultures'.

20. Kervyn, Fiske, Malone, 'Brands as Intentional Agents Framework'; Sevillano, Fiske, 'Stereotypes, Emotions, and Behaviors Associated With Animals'.

21. Simmons, Nelson, Simonsohn, 'A 21 word solution'.

22. Kotzur et al., 'Society Thinks They are Cold and/or Incompetent, but I do Not'.

23. Asbrock, 'Stereotypes of Social Groups in Germany'; Cuddy, Fiske, Glick, 'The BIAS Map'; and Fiske et al., 'Model of (Often Mixed) Stereotype Content'.

24. Koch et al., 'The ABC of Stereotypes about Groups'.

25. Asbrock, 'Stereotypes of Social Groups in Germany'.

26. JASP Team.

27. Fiske et al., 'Model of (Often Mixed) Stereotype Content'.

28. JASP Team.

29. Fiske et al., 'Model of (Often Mixed) Stereotype Content'.

30. Hellmann, 'Bundesliga: Gleiches Geld für alle?' 
31. Fiske et al., 'Model of (Often Mixed) Stereotype Content'.

32. Dmowski, 'Geographical Typology of European Football Rivalries'.

\section{Bibliography}

Asbrock, F. 'Stereotypes of Social Groups in Germany in Terms of Warmth and Competence'. Social Psychology 41, no.2 (2010): 76-81. https://doi.org/10.1027/1864$\underline{9335 / \mathrm{a} 000011}$

Cialdini, R. B., R.J. Borden, A. Thorne, M. R. Walker, S. Freeman, and L. R. Sloan. 'Basking in Reflected Glory: Three (Football) Field Studies'. Journal of Personality and Social Psychology 34, no.3 (1976): 366-375. https://doi.org/10.1037/0022-3514.34.3.366

Cuddy, A. J. C., S. T. Fiske, and P. Glick. 'The BIAS Map: Behaviors from Intergroup Affect and Stereotypes'. Journal of Personality and Social Psychology 92, no.4 (2007): 1631-648. https://doi.org/10.1037/0022-3514.92.4.631

Cuddy, A. J., S. T. Fiske, V. S. Kwan, P. Glick, S. Demoulin, J.P. Leyens, M. H. Bond, J.C. Croizet, N. Ellemers and R. Ziegler, 'Stereotype Content Model across Cultures: Towards Universal Similarities and some Differences'. British Journal of Social Psychology 48, no. 1 (2009): 1-33. https://doi.org/10.1348/014466608X314935

Dinkelaker, M. 'Applaus?', 11 Freunde, August 14, 2020, https://11 freunde.de/artikel/lauter$\underline{\mathrm{b} 1 \% \mathrm{C} 3 \% \mathrm{~B} 6 \mathrm{~d} \sin n / 1408650}$ (accessed February 8, 2021)

Dmowski, S. 'Geographical Typology of European Football Rivalries'. Soccer \& Society 14, no.3 (2013): 331-343. https://doi.org/10.1080/14660970.2013.801264

D'Souza, C. 'The English Premier League: Who is the Most Hated Team?', Bleacher Report, November 13, 2008, https://bleacherreport.com/articles/81219-the-english-premier-leaguewho-is-the-most-hated-team (accessed February 8, 2021) 
Everton Spare Tickets [@evertonspares] (2019, May 12), ‘Arriving home', Twitter, https://twitter.com/evertonspares/status/1127688806042361863?s=20 (accessed February 8, 2021)

Fiske, S. T. 'Stereotype Content: Warmth and Competence Endure'. Current Directions in Psychological Science 27, no.2 (2018): 67-73. https://doi.org/10.1177/0963721417738825

Fiske, S. T., A.J.C. Cuddy, P. Glick, and J. Xu. 'A Model of (Often Mixed) Stereotype Content: Competence and Warmth Respectively Follow from Perceived Status and Competition'. Journal of Personality and Social Psychology 82, no.6 (2002): 878-902. https://doi.org/10.1037/0022-3514.82.6.878

Havard, C. T. 'Glory Out of Reflected Failure: The Examination of How Rivalry Affects Sport Fans'. Sport Management Review 17, no.3 (2013): 243-253.

$\underline{\text { https://doi.org/10.1016/j.smr.2013.09.002 }}$

Hellmann, F. 'Bundesliga: Gleiches Geld für alle?', Sportschau, July 7, 2020, https://www.sportschau.de/fussball/bundesliga/-verteilungskampf-um-die-fernsehgelder$\underline{100 . h t m l}$ (accessed February 8, 2021)

JASP Team (2020). JASP (Version 0.14.1) [Computer software].

Kervyn, N., S. T. Fiske, and C. Malone. 'Brands as Intentional Agents Framework: How Perceived Intentions and Ability can Map Brand Perception'. Journal of Consumer Psychology 22, no. 2 (2012): 166-176. https://doi.org/10.1016/j.jcps.2011.09.006

Koch, A., R. Imhoff, R. Dotsch, C. Unkelbach, and H. Alves. 'The ABC of Stereotypes about Groups: Agency/socioeconomic Success, Conservative-Progressive Beliefs, and Communion`. Journal of Personality and Social Psychology 110, no. 5 (2016): 675-709. $\underline{\text { https://doi.org/10.1037/pspa0000046 }}$

Kotzur, P. F., S. Veit, A. Namyslo, M. A. Holthausen, U. Wagner and R. Yemane. 'Society Thinks They are Cold and/or Incompetent, but I do Not' Stereotype Content Ratings Depend on Instructions and the Social Group's Location in the Stereotype Content Space'. British 
Journal of Social Psychology 59, no. 4 (2020): 1018-1042.

\section{https://doi.org/10.1111/bjso.12375}

Oltermann, P. 'Bayern Munich are the club Germans love to hate', The Guardian, May 25, 2013, https://www.theguardian.com/commentisfree/2013/may/25/bayern-munich-germanslove-to-hate (accessed February 8, 2013).

Porat, A. B. 'Football Fandom: A bounded Identification'. Soccer \& Society 11, no. 3 (2010): 277-290. https://doi.org/10.1080/14660971003619594

Russell D., 'Associating with Football: Social Identity in England 1863-1998', in Football Cultures and Identities (London, Palgrave Macmillan, 1999), 15-28. https://doi.org/10.1057/9780230378896_2

Sevillano, V., and S. T. Fiske. 'Stereotypes, Emotions, and Behaviors Associated With Animals: A Causal Test of the Stereotype Content Model and BIAS Map'. Group Processes and Intergroup Relations 22, no.6 (2019): 879-900. https://doi.org/10.1177\%2F1368430219851560

Simmons, J. P., D. L. Nelson, and U. Simonsohn. 'A 21 word solution', SSRN, (2012). https://dx.doi.org/10.2139/ssrn.2160588

Spiegel, 'Nach Quizshow Gladbach will Fan belohnen - weil er den 1. FC Köln als Antwort verweigerte', Spiegel Sport, July 28, 2020, https://www.spiegel.de/sport/fussball/gefragtgejagt-borussia-moenchengladbach-will-fan-fuer-ausbleibende-antwort-belohnen-a413aae4f-99a3-489e-b7d9-b023db6d4988 (accessed February 8, 2021)

Statista. 'Most valuable football brands worldwide in 2020 (in million U.S. dollars)', https://www.statista.com/statistics/234493/football-clubs-in-europe-by-brand-value/ (accessed February 8, 2021)

Tajfel. H., Turner, J., 'An Integrative Theory of Intergroup Conflict', in The Social Psychology of Intergroup Relations (Monterey, Brooks/Cole, 1979), 33-47. 
Woisetschläger, D.M., Backhaus, C., Hagebölling, M., and O’Neill, C. 'Fußballstudie 2019. Die Markenlandschaft der Fußball-Bundesliga’, http://www.fussballstudie.de/download.php?f=Fussballstudie 2019.pdf (accessed February $8,2021)$ 


\section{Supplemental Material}

Table S1: Measures of Studies 1 and 2

\begin{tabular}{|c|c|c|}
\hline Construct & Items & Scale \\
\hline Age & - What is your age (in years)? & \\
\hline Gender & - What is your gender? & Female, Male, Other/Non-binary \\
\hline Interest in football & - I have no or little interest in football & $\begin{array}{l}\text { 1. Strongly disagree, } 2 \text {. Disagree somewhat, } 3 \text {. Neither agree nor disagree, } 4 \text {. } \\
\text { Agree somewhat, } 5 \text {. Strongly agree }\end{array}$ \\
\hline Favourite club & $\begin{array}{l}\text { - Are you interested in a particular professional football club? } \\
\text { - Which professional football club are you particularly interested in? }\end{array}$ & Yes, No \\
\hline $\begin{array}{l}\text { Relationship to } \\
\text { club }\end{array}$ & $\begin{array}{l}\text { - How would you describe your fan relationship with the club you are } \\
\text { personally interested in? }\end{array}$ & $\begin{array}{l}\text { 1. I sympathize with the club, which means I am interested in results, but I } \\
\text { rarely watch the matches live., } 2 \text {. I am a fan of the club, but I watch the games } \\
\text { almost exclusively on television., 3. I am a fan of the club and go to the } \\
\text { stadium regularly for home games. But I watch the away games mostly on } \\
\text { television., 4. I go to the stadium regularly and go to the away games } \\
\text { regularly., 5. I live for this club. I try to watch every match live on location and } \\
\text { I am active in the fan scene. }\end{array}$ \\
\hline Competence & $\begin{array}{l}\text { - As viewed by society, how competent are the directors of the club? } \\
\text { - As viewed by society, how confident is this club? } \\
\text { - As viewed by society, how competitive is this club? }\end{array}$ & 1. Not at all, 2. Rather less, 3. Neutral, 4. Rather more, 5. Extremely \\
\hline Warmth & $\begin{array}{l}\text { - As viewed by society, how much "warmth" does this club radiate? } \\
\text { - As viewed by society, how good-natured is this club? } \\
\text { - As viewed by society, how friendly are the directors of the club? }\end{array}$ & $\begin{array}{l}\text { 1. Not/None at all, 2. Rather less, 3. Neutral, 4. Rather more, 5. Extremely/A } \\
\text { lot }\end{array}$ \\
\hline $\begin{array}{l}\text { Beliefs } \\
(\text { only Study 1) }\end{array}$ & $\begin{array}{l}\text { - As viewed by society, how traditional is the club? } \\
\text { - As viewed by society, how conservative is the club? } \\
\text { - As viewed by society, how modern are the structures and approaches of } \\
\text { this club? }\end{array}$ & 1. Not at all, 2. Rather less, 3. Neutral, 4. Rather more, 5. Extremely \\
\hline $\begin{array}{l}\text { Preferred money } \\
\text { distribution }\end{array}$ & $\begin{array}{l}\text { - Should the club receive more or less money (e.g. state aid, TV money } \\
\text { etc.) than other clubs? }\end{array}$ & $\begin{array}{l}\text { 1. Should get much less, } 2 \text {. Should rather get less, } 3 \text {. Should get neither less nor } \\
\text { more, } 4 \text {. Should rather get more, } 5 \text {. Should get much more }\end{array}$ \\
\hline Overall assessment & - How do you think this club is rated overall? & $\begin{array}{l}\text { 1. Very negatively, } 2 \text {. Rather negatively, } 3 \text {. Neutral, } 4 \text {. Rather positively, } 5 . \\
\text { Very positively }\end{array}$ \\
\hline Emotions & $\begin{array}{l}\text { - As viewed by society, how much contempt does this club elicit? } \\
\text { - As viewed by society, how much envy does this club elicit? } \\
\text { - As viewed by society, how much admiration does this club elicit? } \\
\text { - As viewed by society, how much pity does this club elicit? }\end{array}$ & 1. None at all, 2. Rather less, 3. Neutral, 4. Rather more, 5. A lot \\
\hline
\end{tabular}


Table S2: Frequencies of favourite clubs (Study 1)

\begin{tabular}{|c|c|c|c|c|c|c|c|c|c|}
\hline Augsburg & $\begin{array}{l}\text { Bayern } \\
\text { Munich }\end{array}$ & $\begin{array}{l}\text { Arminia } \\
\text { Bielefeld }\end{array}$ & $\begin{array}{l}\text { Borussia } \\
\text { M'gladbach }\end{array}$ & $\begin{array}{c}\text { Borussia } \\
\text { Dortmund }\end{array}$ & $\begin{array}{l}\text { Eintracht } \\
\text { Frankfurt }\end{array}$ & $\begin{array}{c}\mathrm{SC} \\
\text { Freiburg }\end{array}$ & $\begin{array}{l}\text { Hertha } \\
\text { BSC }\end{array}$ & Hoffenheim & $\begin{array}{c}\text { FC } \\
\text { Köln }\end{array}$ \\
\hline $\begin{array}{r}1 \\
(0.15 \%) \\
\end{array}$ & $\begin{array}{r}80 \\
(11.75 \%) \\
\end{array}$ & $\begin{array}{r}13 \\
(1.91 \%) \\
\end{array}$ & $\begin{array}{r}38 \\
(5.58 \%) \\
\end{array}$ & $\begin{array}{r}73 \\
(10.72 \%) \\
\end{array}$ & $\begin{array}{r}74 \\
(10.87 \%) \\
\end{array}$ & $\begin{array}{r}6 \\
(0.88 \%) \\
\end{array}$ & $\begin{array}{r}26 \\
(3.28 \%) \\
\end{array}$ & $\begin{array}{r}9 \\
(1.32 \%) \\
\end{array}$ & $\begin{array}{r}25 \\
(3.67 \%) \\
\end{array}$ \\
\hline
\end{tabular}

\begin{tabular}{|c|c|c|c|c|c|c|c|c|c|}
\hline $\begin{array}{c}\text { Bayer } \\
\text { Leverkusen }\end{array}$ & $\begin{array}{c}\text { FSV Mainz } \\
05\end{array}$ & $\begin{array}{c}\mathrm{RB} \\
\text { Leipzig }\end{array}$ & $\begin{array}{c}\text { Schalke } \\
04\end{array}$ & $\begin{array}{c}\text { VfB } \\
\text { Stuttgart }\end{array}$ & $\begin{array}{l}\text { Union } \\
\text { Berlin }\end{array}$ & $\begin{array}{l}\text { Werder } \\
\text { Bremen }\end{array}$ & $\begin{array}{c}\text { VfL } \\
\text { Wolfsburg }\end{array}$ & $\begin{array}{l}\text { other or } \\
\text { more than } \\
\text { one team }\end{array}$ & $\begin{array}{c}\text { no favourite } \\
\text { team }\end{array}$ \\
\hline $\begin{array}{r}20 \\
(2.94 \%) \\
\end{array}$ & $\begin{array}{r}22 \\
(3.23 \%) \\
\end{array}$ & $\begin{array}{r}7 \\
(1.03 \%) \\
\end{array}$ & $\begin{array}{r}29 \\
(4.26 \%) \\
\end{array}$ & $\begin{array}{r}35 \\
(5.14 \%) \\
\end{array}$ & $\begin{array}{r}12 \\
(1.76 \%) \\
\end{array}$ & $\begin{array}{r}23 \\
(3.38 \%) \\
\end{array}$ & $\begin{array}{r}46 \\
(6.75 \%) \\
\end{array}$ & $\begin{array}{r}94 \\
(13.80 \%) \\
\end{array}$ & $\begin{array}{r}48 \\
(7.05 \%) \\
\end{array}$ \\
\hline
\end{tabular}


Table S3: Sample sizes as well as means and standard deviations for variables of interest for all clubs (Study 1)

\begin{tabular}{|c|c|c|c|c|c|c|c|c|c|}
\hline Club & $\mathbf{N}$ & Competence & Warmth & $\begin{array}{c}\text { Money } \\
\text { distribution }\end{array}$ & $\begin{array}{c}\text { Overall } \\
\text { assessment }\end{array}$ & Contempt & Envy & Admiration & Pity \\
\hline Augsburg & 337 & $2.71(0.63)$ & $3.09(0.75)$ & $3.15(0.68)$ & $3.18(0.77)$ & $2.22(0.87)$ & $2.11(0.84)$ & $2.40(0.92)$ & $2.50(0.91)$ \\
\hline Bayern Munich & 9 & $51(0.51)$ & $53(0.95)$ & & 22) & $90(0.99)$ & $4.26(0.89)$ & $3.75(1.01)$ & \\
\hline Arminia Bielefeld & 28 & ) & 6) & 5) & & 2.14 & 2.10 & 2.52 & 2.7 \\
\hline Borussia M'gladbac & 188 & $3.83(0.59)$ & $67(0.67)$ & & $4.10(0.62)$ & $2.08(0.70)$ & $3.01(0.85)$ & $3.54(0.73)$ & $1.99(0.82)$ \\
\hline Borussia Dort & 224 & 10 & 11 & & & 2.6 & 3.56 & 3.7 & 2. \\
\hline Eintr & 179 & & & & & & & & \\
\hline $\mathrm{SCF}$ & 205 & & & & & & & & \\
\hline Hertha BSC & חבי & & 020 & 2.6 & & 3. & & & \\
\hline Hoffenhei & & & & & & & & & \\
\hline FC Köln & 186 & & & & & & & & \\
\hline & 167 & & & & & & & & \\
\hline FSV Mai & & & & & & & & & \\
\hline RB Le & & & & & & & & & \\
\hline Schalke 04 & 314 & 2.4 & 2.53 & & 2.7 & 3.3 & $2.12(0.91)$ & $2.55(1.02)$ & $3.23(1.14)$ \\
\hline VfB Stuttga & 224 & $2.76(0.71)$ & $2.86(0.69)$ & & $3.13(0.79)$ & $2.52(0.80)$ & $2.30(0.84)$ & $2.53(0.90)$ & $2.83(0.97)$ \\
\hline Unior & 14 & & & & $3.83(0.86)$ & $2.19(0.95)$ & $2.65(0.92)$ & 3.31( & \\
\hline Werder Bremen & 225 & & & & & & & & 3.08 \\
\hline VfL Wolfsburg & 294 & $3.01(0.71)$ & $2.33(0.81)$ & $2.38(0.94)$ & $2.37(0.88)$ & $3.49(0.97)$ & $2.35(0.98)$ & $2.02(0.81)$ & $2.37(1.02)$ \\
\hline
\end{tabular}

Note: Standard deviations are displayed in parentheses. 
Table S4: Means and standard deviations for competence and warmth for clusters in Study 1

\begin{tabular}{lll}
\hline & Competence & Warmth \\
\hline Cluster 1 & $4.23(0.25)$ & $2.53(0.58)$ \\
Cluster 2 & $3.02(0.43)$ & $3.52(0.31)$ \\
Cluster 3 & $2.93(0.35)$ & $2.51(0.22)$
\end{tabular}


Table S5: Frequencies of favourite clubs (Study 2)

\begin{tabular}{|c|c|c|c|c|c|c|c|c|c|c|}
\hline Arsenal & Aston Villa & $\begin{array}{l}\text { Brighton \& } \\
\text { Hove } \\
\text { Albion }\end{array}$ & Burnley & Chelsea & $\begin{array}{l}\text { Crystal } \\
\text { Palace }\end{array}$ & Everton & Fulham & Leeds United & $\begin{array}{l}\text { Leicester } \\
\text { City }\end{array}$ & Liverpool \\
\hline $\begin{array}{r}86 \\
(10.59 \%) \\
\end{array}$ & $\begin{array}{r}17 \\
(2.09 \%) \\
\end{array}$ & $\begin{array}{r}7 \\
(0.86 \%) \\
\end{array}$ & $\begin{array}{r}4 \\
(0.49 \%)\end{array}$ & $\begin{array}{r}51 \\
(6.28 \%) \\
\end{array}$ & $\begin{array}{r}6 \\
(0.74 \%) \\
\end{array}$ & $\begin{array}{r}15 \\
(1.85 \%) \\
\end{array}$ & $\begin{array}{r}2 \\
(0.25 \%) \\
\end{array}$ & $\begin{array}{r}14 \\
(1.72 \%) \\
\end{array}$ & $\begin{array}{r}14 \\
(1.72 \%)\end{array}$ & $\begin{array}{r}131 \\
(16.13 \%) \\
\end{array}$ \\
\hline
\end{tabular}

\begin{tabular}{rrrrrrrrrrr}
\hline $\begin{array}{c}\text { Manchester } \\
\text { City }\end{array}$ & $\begin{array}{c}\text { Manchester } \\
\text { United }\end{array}$ & $\begin{array}{c}\text { Newcastle } \\
\text { United }\end{array}$ & $\begin{array}{c}\text { Sheffield } \\
\text { United }\end{array}$ & Southampton & $\begin{array}{c}\text { Tottenham } \\
\text { Hotspur }\end{array}$ & $\begin{array}{c}\text { West } \\
\text { Bromwich } \\
\text { Albion }\end{array}$ & $\begin{array}{c}\text { West Ham } \\
\text { United }\end{array}$ & $\begin{array}{c}\text { Wolverhampton } \\
\text { Wanderers }\end{array}$ & $\begin{array}{c}\text { other or } \\
\text { more than } \\
\text { one team }\end{array}$ & $\begin{array}{c}\text { no } \\
\text { favourite } \\
\text { team }\end{array}$ \\
\hline 34 & 132 & 25 & 7 & & 10 & 57 & 3 & 25 & 112 & 50 \\
$(4.19 \%)$ & $(16.26 \%)$ & $(3.08 \%)$ & $(0.86 \%)$ & $(1.23 \%)$ & $(7.02 \%)$ & $(0.37 \%)$ & $(3.08 \%)$ & $(1.23 \%)$ & $(13.79 \%)$ & $(6.16 \%)$ \\
\hline
\end{tabular}


Table S6: Sample sizes as well as means and standard deviations for variables of interest for all clubs (Study 2)

\begin{tabular}{|c|c|c|c|c|c|c|c|c|c|}
\hline Club & $\mathbf{N}$ & Competence & Warmth & $\begin{array}{c}\text { Money } \\
\text { distribution }\end{array}$ & $\begin{array}{c}\text { Overall } \\
\text { assessment }\end{array}$ & Contempt & Envy & Admiration & Pity \\
\hline Arsenal & 211 & $3.35(0.90)$ & $2.94(0.77)$ & $2.88(0.68)$ & $3.48(1.02)$ & $3.09(0.91)$ & $3.13(0.98)$ & $3.28(0.93)$ & $2.45(1.09)$ \\
\hline Aston Villa & 201 & $3.09(0.72)$ & $3.23(0.60)$ & $3.03(0.64)$ & $3.21(0.89)$ & $2.74(0.76)$ & $2.50(0.87)$ & $3.00(0.89)$ & $2.73(0.86)$ \\
\hline Brighton \& Hove Albion & 202 & $2.77(0.63)$ & $3.42(0.60)$ & $3.20(0.58)$ & $3.20(0.89)$ & $2.36(0.87)$ & $2.15(0.80)$ & $2.90(0.90)$ & $2.91(0.93)$ \\
\hline Burnley & 190 & $2.71(0.67)$ & $3.34(0.68)$ & $3.14(0.70)$ & $3.03(0.89)$ & $2.43(0.88)$ & $2.05(0.77)$ & $2.93(0.89)$ & $3.07(0.96)$ \\
\hline Chelsea & 189 & $4.15(0.57)$ & $2.70(0.82)$ & $2.68(0.82)$ & $3.58(0.99)$ & $3.54(0.88)$ & $3.70(0.84)$ & $3.44(0.97)$ & $1.99(0.93)$ \\
\hline Crytsal Palace & 199 & $2.99(0.67)$ & $3.18(0.58)$ & $3.06(0.53)$ & $3.08(0.82)$ & $2.58(0.81)$ & $2.36(0.87)$ & $2.85(0.77)$ & $2.71(0.87)$ \\
\hline Everton & 212 & $3.53(0.73)$ & $3.38(0.75)$ & $2.97(0.61)$ & $3.56(0.84)$ & $2.80(0.90)$ & $2.75(0.90)$ & $3.22(0.83)$ & $2.52(0.91)$ \\
\hline Fulham & 196 & $2.72(0.67)$ & $3.24(0.61)$ & $2.93(0.52)$ & $3.11(0.84)$ & $2.48(0.83)$ & $2.16(0.83)$ & $2.80(0.85)$ & $3.09(0.85)$ \\
\hline Leeds & 190 & $3.29(0.83)$ & $3.08(0.83)$ & $3.12(0.64)$ & $3.22(1.00)$ & $3.00(0.98)$ & $2.56(0.94)$ & $3.16(0.96)$ & $2.62(0.96)$ \\
\hline Leicester & 194 & $3.88(0.68)$ & $3.84(0.69)$ & $3.18(0.56)$ & $4.12(0.75)$ & $2.35(0.89)$ & $2.85(0.92)$ & $3.88(0.83)$ & $2.49(0.96)$ \\
\hline Liverpool & 217 & $4.36(0.66)$ & $3.52(0.89)$ & $3.00(0.88)$ & $4.08(1.00)$ & $3.18(1.05)$ & $3.77(0.95)$ & $4.02(0.92)$ & $2.13(1.00)$ \\
\hline Manchester City & 200 & $4.26(0.62)$ & $2.91(0.74)$ & $2.55(0.92)$ & $3.68(0.94)$ & $3.34(0.88)$ & $3.83(0.94)$ & $3.49(0.98)$ & $1.95(0.94)$ \\
\hline Manchester United & 192 & $3.74(0.87)$ & $2.83(0.97)$ & $2.77(0.99)$ & $3.58(1.22)$ & $3.65(1.09)$ & $3.92(1.05)$ & $3.66(1.12)$ & $2.05(1.10)$ \\
\hline Newcastle United & 191 & $2.64(0.95)$ & $2.92(0.86)$ & $3.02(0.63)$ & $2.98(1.01)$ & $2.92(0.91)$ & $2.51(0.87)$ & $2.96(0.92)$ & $3.04(1.07)$ \\
\hline Sheffield United & 218 & $2.87(0.76)$ & $3.28(0.69)$ & $3.14(0.69)$ & $3.19(0.91)$ & $2.51(0.83)$ & $2.37(0.86)$ & $3.00(0.98)$ & $2.92(0.91)$ \\
\hline Southampton & 208 & $3.28(0.78)$ & $3.42(0.63)$ & $3.12(0.66)$ & $3.39(0.87)$ & $2.44(0.88)$ & $2.47(0.82)$ & $3.14(0.87)$ & $2.71(0.99)$ \\
\hline Tottenham Hotspur & 186 & $3.86(0.76)$ & $3.12(0.88)$ & $2.91(0.82)$ & $3.66(1.00)$ & $3.18(0.91)$ & $3.22(0.96)$ & $3.39(0.98)$ & $2.49(1.10)$ \\
\hline West Bromwich Albion & 211 & $2.58(0.68)$ & $3.13(0.63)$ & $3.06(0.81)$ & $2.81(0.83)$ & $2.52(0.84)$ & $2.15(0.85)$ & $2.66(0.82)$ & $3.09(1.06)$ \\
\hline West Ham United & 189 & $2.87(0.87)$ & $2.84(0.78)$ & $2.95(0.57)$ & $2.92(0.95)$ & $2.88(0.92)$ & $2.49(0.94)$ & $2.75(0.87)$ & $2.66(1.04)$ \\
\hline Wolverhampton & 226 & $3.51(0.81)$ & $3.35(0.66)$ & $3.15(0.61)$ & $3.60(0.80)$ & $2.63(0.86)$ & $2.68(0.91)$ & $3.27(0.86)$ & $2.53(0.91)$ \\
\hline
\end{tabular}

Note: Standard deviations are displayed in parentheses. 
Table S7: Means and standard deviations for competence and warmth for clusters in Study 2

\begin{tabular}{lll}
\hline & Competence & Warmth \\
\hline Cluster 1 & $3.71(0.42)$ & $3.50(0.20)$ \\
Cluster 2 & $3.87(0.36)$ & $2.90(0.15)$ \\
Cluster 3 & $2.85(0.22)$ & $3.17(0.18)$
\end{tabular}

